\title{
Impact of the COVID-19 pandemic on tourism operations and resilience: stakeholders' perspective in Sri Lanka
}

\author{
A.C.I.D. Karunarathne, J.P.R.C. Ranasinghe and U.G.O. Sammani \\ Department of Tourism Studies, Uva Wellassa University, \\ Badulla, Sri Lanka, and \\ K.J.T. Perera \\ Department of Management Sciences, Uva Wellassa University, \\ Badulla, Sri Lanka
}

\begin{abstract}
Purpose - The tourism industry has been extensively affected by numerous disasters throughout its history including 30 decades of ethnic war, the tsunami disaster in 2004 and the Easter Sunday attack in 2019 substantially impacted the resources and capacities of the tourism industry in Sri Lanka. This study aims to explore the impact of COVID-19 on Sri Lanka as a tourism destination and the tourism industry as a resilient sector of the economy.

Design/methodology/approach - This qualitative study was conducted from July 2020 to September 2020 focusing on the perspectives of multi-level stakeholders in the tourism and hospitality industry in three distinct areas of Sri Lanka, namely, the coastal area, hill country and cultural triangle. The data were collected from 15 stakeholders via semistructured interviews. Convenience sampling method was used to choose the sample and thematic analysis was occupied to meet the study objectives.

Findings - This study will help to reframe the resources and capacities of the country as an emerging destination identifying the diverse credentials from the perspective of different stakeholders to embed the essential resilience after the pandemic.

Research limitations/implications - The prevailing lockdown situation and travel restrictions within the country was a huge challenge during the data collection process. Further to that, the respondents were reluctant to meet outsiders owing to the health threat, and hence some important stakeholders were missing from the study.

Originality/value - This study proposes effective measures to build up a robust destination, necessary strategic planning for policymakers and provisions for stakeholders in the industry to address the health and safety of travelers in the case of future potential health epidemics.
\end{abstract}

Keywords Tourism industry, Health pandemics, COVID-19, Destination resilience,

Stakeholders' perception

Paper type Research paper

\section{Introduction}

Almost ten years after the end of its civil war, Sri Lanka was recognized as the best country in the world to visit in 2019 by the Lonely Planet (Wilson, 2018). Moreover, the Trip Expert, which is a leading travel agent in the world, has named Sri Lanka as the "Best Emerging Destination for 2019" owing to its pristine beaches, mountain and UNESCO World Heritage sites (Xinhua, 2018). In the 1960s, tourism was recorded as a

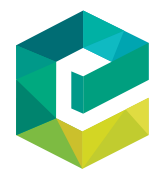


WHATT

13,3

commercially viable economic segment in Sri Lanka and flourished over the past few decades with unprecedented growth in the industry. However, the tourism industry was extensively affected with numerous disasters from 1960 until today. The insurrections propelled the rebel movement in the country in 1973, 1983 and 1987 spawned immeasurable losses to the tourism industry. The 30 decades of ethnic war with terrorists and the tsunami disaster in 2004 substantially impacted the resources and capacities of the tourism industry in Sri Lanka. Despite the disastrous events and at the end of the civil war in 2009, the Sri Lankan tourism industry recorded a two digit growth rate for both international tourists' arrivals and tourism revenues (Weerathunga et al., 2020). This intensive growth was interrupted last year, with the Easter Sunday Attack [1] which caused a US\$1.5bn loss in tourism income of the country (Silva, 2019). However, the tourism industry was able to recover rapidly owing to efforts made by the government, security forces, the Sri Lankan Tourism Development Authority (SLTDA) and the Sri Lanka Tourism Promotional Bureau. As a result, Sri Lankan tourism grew by 1.9 million tourists by the end of 2019 despite the unfortunate security breach (SLTDA, 2020). Even with many dark experiences over past few decades, Sri Lanka has demonstrated its physical and psychological resilience and the nation's strength to way forward as an emerging destination exhibiting significant milestones in the international tourism arena (Samarathunga, 2020).

The potential long-term global impacts of COVID-19 are still unclear. The island nation's tourism sector is the most deeply affected by the global viral outbreak; it is expected to have a significant impact on tourism incomes for the remainder of the year (Xinhua, 2018). Owing to the heavy toll of tourism on the country's economy, it is important to study how the resilience of the industry might shape the recovery of its main sub-sectors once the pandemic subsides (Ranasinghe et al., 2020). The present COVID-19 outbreak is a stark reminder of the vulnerability of the tourism and hospitality industry against external shocks. Thousands of tourist facilities, from blue-chip enterprises to beach souvenir vendors, have entered an unprecedented era of zero sales, leaving the industry's stakeholders in a dilemma on the next steps (Samarathunga, 2020). In this context, Sri Lanka, as an emerging tourism destination, has given priority for tourism development in the local economy.

Tourism is one of the most impacted socioeconomic sectors of the country during the COVID-19 outbreak. Furthermore, the tourism industry plays a vital role in the Sri Lankan economic sector by contributing $12.5 \%$ of its gross domestic product (GDP) and 250,000 direct and up to two million indirect employment opportunities. According to Hettiarachchi (2020), Secretary to the Tourism and Aviation Ministry in Sri Lanka, the new pandemic is global and will have a much longer effect on tourism than historical crises and restoration and revitalization of the sector will involve the collective efforts of all stakeholders of the industry. The long-term benefits within the tourism industry will result from a participatory community participation phase of resilience building (Yusuf et al., 2019). Hence, the study aims to reframe the environmental relationship of stakeholders within the diverse backgrounds of the tourism industry in Sri Lanka and identify the perception of different stakeholders to embedding resilience into strategic planning in Sri Lanka.

\section{Literature review}

\section{Tourism in Sri Lanka}

Sri Lanka, formerly known as Ceylon, is a small island (65,610 square miles) in the Indian Ocean off the southeastern coast of India, $880 \mathrm{~km}$ north of the equator. Occupying a strategic location on ancient sea routes, the natural and cultural resources of this tropical island have attracted travelers for centuries. The country experiences a diverse climate and weather 
conditions throughout the year with $7-33^{\circ} \mathrm{C}$ temperatures from the hill country to low lands and southwestern monsoon and northeastern monsoon rains from May to July and December to January, respectively (Arsarathnam, 2004).

There have been a variety of obstacles to the growth of tourism in Sri Lanka, especially as a result of the recurring civil war and the 2004 Asian Tsunami. Tourism has been unable to thrive for several years (SLTDA, 2007). Emerging destinations such as Sri Lanka play economically and socially significant roles in the competitive tourism market (Karunarathne, 2015) and, Sri Lanka is still severely shattered with several vulnerable crises. Cochrane (2008) indicated that no other destination like Sri Lanka has been affected by a series of long-lasting and severe crises. Further, the issues related to contemporary tourism development in Sri Lanka are conserving and sustaining, diversifying and diversifying, benefiting and costing, building and destruction and future and backward linkages, as tourism linkages prevail across the relatively diverse economy (Cochrane, 2008).

\section{Sri Lanka as an emerging tourism destination}

Emerging destinations have distinctive features from the tourism destinations in the maturity phase. With the robust association of forward and backward linkages (Karunarathne, 2015), the tourism features know in emerging destinations where tourism has just been recognized as a major socio-economic development tool and the community has expressed willingness to utilize tourism potential to enhance their socio-economic wellbeing (Esu and Ebitu, 2010). According to the UNWTO (2015), arrivals in emerging destinations between 2010 and 2030 are forecasted to increase twice as fast as in advanced economies, achieving $57 \%$ of the market share. Mature destinations in Northern and Western Europe and North America are expected to experience relatively slower growth over the next two decades. On the contrary, Africa, the Middle East, Asia and the Pacific are the regions that are predicted to develop faster. As a result, tourism in emerging markets is catching growing attention (Cohen et al., 2014).

According to Ranasinghe et al. (2020), Sri Lanka is a country that plays a key role in developing nations relying heavily on the service sector of the tourism industry. In the last year, the contribution of travel and tourism to GDP is $12.5 \%$ and the contribution of travel and tourism to GDP (growth is $11.4 \%$. Hence, it is also clear that the tourism industry is facilitating countries to grow massively, and Sri Lanka can be considered as emerging tourism destinations, that play a vital role in its socio-economic sector.

\section{Impact of COVID-19}

The pandemic situation of COVID-19 has had a significant effect on the economic growth of almost every country in the world. It has triggered the biggest downturn in the economy in history. More advanced economies, such as the USA, the UK, Japan and Europe, are also witnessing a slowdown in their economies because of the spread of COVID-19. The World Trade Organization predicts that trade activities will fall by $32 \%$ in 2020 . Poor economic performance is because of weak demand, disruption of the supply chain, travel restrictions and the lockdown strategy, which are protective steps to further spread the virus. Scholars have established the effect of various past epidemics on the economy and the tourism sector. Previous studies have shown that such pandemics have relatively less effect than the 2020 outbreak of COVID-19 (Korinth and Ranasinghe, 2020). As per the WTTC (2020), the tourism industry is more likely to recover more slowly than other sectors of the economy, as past pandemics have taken more than 19 months to recover.

The Asian Development Bank projected at the beginning of March that Sri Lanka's tourism revenues could fall from US\$107m to US\$319m (PWC, 2020), with actual revenue 
WHATT

13,3

losses likely to be much higher than expected because the situation has escalated over time. According to SLTDA statistics in 2018, 169,003 and 219,484 employees were employed as direct and indirect employees, respectively, in the tourism sector (SLTDA, 2019). As of today, the vast majority of these workers are temporarily unemployed because of the closure of hotels and restaurants, airlines, travel agencies, tourist shops and so on. This has made a massive impact on families who were totally dependent on tourism. On the other hand, tourism investors are facing a financial crisis without being able to sustain an adequate cash flow to repay debts, pay wages and other necessary maintenance work on assets (Samarathunga, 2020).

Sri Lanka, as a country with little experience of global health epidemics in recent decades, did not have a disaster response plan for large-scale multi-sector global pandemic such as COVID-19. However, with this limited experience, Sri Lanka reported being the first country to implement mitigation and control measures essential for COVID-19 after China (Ranasinghe et al., 2020). Samarathunga (2020) indicates that tourists' arrival to a destination mainly depends on three factors as destination area variables, generating area variables and transit area variables; COVID-19 has significantly impacted all three of these factors. The virus and policies to help contain its spread limited international tourists' arrivals to the lowest level in the recorded history of the industry.

\section{Destination resilience}

The resilience factor of a tourist destination can be defined as the capability of stakeholders to respond against shocks that depend on planning, anticipation and responsiveness. It is simultaneously a decentralized mechanism and a collective response that offers various answers and ensures consistency in the creation of sufficient capability (Folke, 2005; Becken, 2013). According to Ungar (2003), resilience is defined as a collection of internally focused capacities, characteristics or behaviors, as well as the structural conditions (social, cultural, and political) that enable individuals to adapt in the face of adversity. Tourism industry stakeholders are constantly faced with a variety of system shocks and stressors that require them to cope with and adjust to emerging contexts on a seemingly ongoing basis (Scott et al., 2008). In the literature, tourism resilience is first described as a means of enhancing sustainability following an ecological or environmental catastrophe and proposes alternatives to sustainable development (Lew, 2014; Dahles and Susilowati, 2015), even if the concept could become a buzzword (Davoudi, 2012).

As resilience focuses on social and structural interactions, it is understood as a mechanism and refers to the capacity to adjust and adapt to resolve conflict-related vulnerabilities, extremism, climate change, natural disasters, financial and fiscal imbalances, excessive urbanization, wealth inequalities, aging populations or technological change. Moreover, resilience refers, by definition, to the ability of the socio-economic system to cope with disruptions, absorb exogenous and endogenous shocks and adjust its organization, form change through continuous creativity and learning (Hudson, 2010). Faced with an uncertain future, destinations that tend to be in a less disadvantaged, more resilient position are those that have a more diversified offer, are less reliant on a specific market and have opted for qualitative rather than quantitative criteria (i.e. development rather than growth). In any event, as Lew (2014) has pointed out, businesses that survive the pandemic will need to make their products more resilient to future pandemics - which health experts will continue to alert - and to be able to respond to the anticipated shift in consumer interests, including increased demand for sustainable products. 


\section{Methodology}

The current study was expected to understand the impact of COVID-19 on Sri Lanka as an emerging tourism destination and the way forward for the resilience. A qualitative study was conducted from July 2020 to September 2020, focusing on the perspective of different stakeholders representing coastal area, hill country and cultural triangle in Sri Lanka. Data collection was carried out during the months of July and September using semistructured interview method. A sample of 15 stakeholders were selected via a convince sample representing two government officials, five hotel managers (two from supplementary lodging sector and three from star graded hotels), four entrepreneurs (art and craft shop owner -1 , restaurant owner -2 , camping operator/facilitator -1 ), one national tour guide, one area tour guide and two residents living in tourism destinations were interviewed representing key tourism destinations in the country representing different tourism hotspots (i.e. Ella - from hill country, Bentota - southern coast and Anuradhapura - cultural triangle). The interview questions were mainly focused related to the impacts and challenges faced by the stakeholders during the COVID-19 pandemic and their perception on resilience of the tourism industry of Sri Lanka. However, with the limitations within the country owing to the high risk of COVID-19 pandemic, researchers managed to physically visit the areas and meet the necessary stakeholders. However, researchers had to make extra effort to meet the selected interviewees as some of the candidates were reluctant to meet the unknown visitors. The data were analyzed using thematic analysis with a qualitative approach, and themes were developed by the researchers using the transcribed interviews of the collected data.

\section{Results and discussion}

Resilience and rebuilding as a tourism destination is not a new archetype for Sri Lanka with the experience earned for past few decades after the greater impacts of Tsunami and ethnic war of 30 decades. However, a virus outbreak is a completely new experience, and hence the immediate measures and actions to blowout the waves of outbreak was challenging. Conversely, the COVID-19 pandemic was successfully managed with lower level of infections and minimum mortality rate during the first few months while many countries were significantly affected with a high level of infections and mortality. With a population of about 21.5 million people, Sri Lanka had only 960 confirmed cases of the novel coronavirus with nine deaths by the month of May 2020 (Mukhopadhyay, 2020), six months after the first case in China. However, the impact made by the pandemic on economic activities was severe and still on the rise. Hence, the current study was extended primarily to understand the impact of COVID-19 on the travel and tourism industry, the third largest foreign exchange earner in the country and the stakeholders' perception to way forward for successful resilience.

Cross-case analysis: impact of COVID-19 pandemic

The findings from the case studies revealed below impacts of COVID-19 which are perceived by the stakeholders.

\section{Loss of employment opportunities}

One major effect of COVID-19 for the tourism industry is the loss of employment of its hospitality and tourism workers. Not only within Sri Lanka but also the global impacts related to foreign remittances which comes from employees in the tourism industry working in the foreign countries that send funds to the country. Subsequently, numerous hotel
Impact of the COVID-19 pandemic 
WHATT

13,3

\section{4}

owners had to decrease the number of employees in operations and continue the operations with the minimum workforce:

We took some decisions for the survival once the pandemic occurred and lockdown announced in the country. We started to cut down utilities such as water, electricity, keeping a proportion of employees at home. And also, we sold some excess stocks such as dairy products, vegetables and fruits, meat, eggs and seafood, some dry products, etc. We made a decision of reducing the number of employees in operation and managing the department with few employees (Respondent 3, Personal Interview, 2020).

In addition, this issue has significantly affected a wider spectrum of workforces who engage in tourism-related jobs, such as tour guides, self-operating and small, and micro enterprises (SME)/micro-operations. The contract employees, temporary employees and trainee staff are also at greater risk in the hotels. Moreover, the majority of the permanent employees have also experienced salary reductions and other benefits were cut off due to the severe economic condition caused by the COVID-19 pandemic. However, the perspective of government stakeholders on the prospects for recovery of the tourism industry is quite optimistic. The view of Respondent 1 was:

The foreign remittances, and Garments and Textiles, first and second places of foreign exchange source for SL is in a high risk and has severely affected. They may not recover sooner. But, more than these two sectors, the third FE generating source, tourism has a high potentiality to recover sooner (Respondent 1, Personal Interview, 2020).

The government sector believes that Sri Lanka has a greater potential of rejuvenating the tourism industry in the country with its diverse array of nature, culture and climate. Even though the industry is severely affected at the moment, there is a greater potential to generate many employment opportunities as tourism is high labor-intensive industry:

I am sure this is a short-term impact. With properly developed strategies and mechanisms, the industry can rebreathe very sooner. And can be developed as it was before the new normal condition (Respondent 1, Personal Interview, 2020).

\section{Financial issues and credit risks}

The prevailing situation of the country has led the tourism industry to wait for a certain period of time to open up the country for tourists. Thus, the main point that researchers have noticed is numerous tourism industry business operators have confronted troubles to reimburse the credits they have acquired from banks and other financial institutions. Furthermore, because of the informal business operators, the majority of them were unable to secure loans from commercial banks, and therefore, most of them obtained loan from private financial institutions at higher interest rates:

This credit risk is the key risk that we have observed. The government has developed several initiatives for these SMEs and tourism business operators to give various reliefs (Respondent 1, Personal Interview, 2020).

Short-term cash flows can be identified as another major financial issue that has been arisen owing to the COVID-19 pandemic. Specially, the SMEs have significantly encountered the issues with short-term cash flows during this pandemic situation:

We cannot pay staff salaries or basic operational cost, so that have dismissed some employees. After the Easter attack and again with COVID 19, we were shocked and the entire businesses collapsed. I have invested all my savings and properties other than the loans to start these 
businesses and expected to earn well and repay bank loans. However, I am currently helpless and unable to continue these businesses with this situation since I have no income to manage the basic expenses (Respondent 8, Personal Interview, 2020).

The waves of the current pandemic is significant and impacts the capacity of loan repayment, specifically the medium, small and micro enterprises (MSMEs); ultimately, this will impact the entire financial system of the county. Consequently, a strong intervention was extended from the government with essential supports to reduce this complexity; however, there are serious practical issues at the operational level. For example, although a new working capital loan was introduced by the government to face such issues, the firm should be a registered operation under the SLTDA to obtain this loan facility. But, in the context of Sri Lanka, the majority of these MSME business operations related to the tourism industry are not registered in SLTDA and they are registered only in the local government. Hence, when they are applying for the facilities declared by the government, they faced plenty of technical problems and then the business operators are helpless taking this point negatively and very disappointed because they believe they are not treated well and not protected enough by the government as noted in the interview of Respondent 5:

I am a small and medium business holder. But, I did not receive any relief after the Easter attack from the government. I have started a new hotel before few days to the Easter attack. I could not operate the business as I expected due to the drop of the industry as a result of bomb blast. I had a big bank loan for that and we were given a one year relief from the government as a moratorium to repay the bank loan (Respondent 5, Personal Interview, 2020).

\section{Management and operational issues of the properties}

According to the perspective of the stakeholders, the tourism industry in Sri Lanka was the top prioritized economic activity prior to the Easter Sunday attack with high occupancy, high arrivals, more investments for new rooms, new facilities and services, more comprehensive marketing campaigns, new strategies institutional and national level, more employments and so on. Furthermore, it has been generated by many direct and indirect employment opportunities for the country before the Easter Sunday attack. However, cancellation and postponement of many investments and implementations were caused by the sudden attack which led the industry to rethink strategies to move forward. The government sector has contributed significantly to the industry's survival:

Some hotels now sell their rooms below the cost, for very lower rates just for the survival. Without foreign tourists, we cannot run, because [the] local market cannot afford the rate of many luxury hotels in the country. I do not think that these hotels can run with such lower rates for a longer period [of] time. If [the] tourism industry is not restarting within next six month, the industry will severely damage and it will be very difficult to recover (Respondent 2, Personal Interview, 2020).

\section{Lower occupancy}

Low occupancy within the accommodation sector was another severe impact caused by the COVID-19 which led to constant cancellation of bookings. Hence, the industry must facilitate a healthy and safer environment for both guests and employees within the current pandemic situations as noted by Respondent 8:
Impact of the COVID-19 pandemic 
WHATT

13,3

Our bookings were continuously getting cancelled. On the other hand, when the pandemic starts, we had a huge amount of food and beverage stock in our stores. Most of them are now expired, and still we had to make the payments to our suppliers even with zero income (Respondent 8, Personal Interview, 2020).

We generally do not focus the local market, so, we are fully closed now since the airport is closed (Respondent 6, Personal Interview, 2020).

During the zero or less occupancy, hoteliers have been challenged with covering salaries and overhead costs such as insurance, electricity, energy among other expenses.

\section{Unstructured and unorganized nature of industry}

The COVID-19 pandemic hit the world suddenly, and Sri Lanka had not fully recovered from the Easter Sunday attack. According to the stakeholders' view, the Easter Sunday Attack is an isolated incident that happened in Sri Lanka and did not create a significant global impact. But, COVID-19 placed the entire world into a struggle to escape from the pandemic with tourism; a highly sensitive market sector was simply not ready for economic environment changes that created a volatile landscape for the tourism and hospitality industries.

Although we are still at a risk of spreading the virus, the most important thing is, we need to decide whether we completely stop the tourism operation or restart with necessary safety precautions in a systematical way (Respondent 1, Personal Interview, 2020).

However, the entire industry is severely affected by the COVID-19 pandemic, and there should be a more strategic approach to recover and build a more resilient tourism industry in Sri Lanka.

\section{Cross-case analysis: remediation and resilience during the pandemic}

\section{Government support}

The key measures taken by the government should be extremely appreciated to protect and uplift the tourism stakeholders in the country. In this approach, all the stakeholders should hand together with the government to meet the expected targets. The key stakeholders were strongly optimistic about tourism potentials and proposed a robust collaborative approach in this perspective:

As a government organization, we give our fullest corporation to facilitate the victims in our province with those reliefs with the support of the banks and other financial institutes (Respondent 1, Personal Interview, 2020).

There was a big political involvement for making tourism a key foreign exchange generating source in the country over the years. Furthermore, they have made many timely decisions which helped to protect many people without getting infected or vanishing with the virus.

\section{Alternative income sources}

Stakeholders recommended engaging in alternative income sources for the tourism service providers considering survival such as local vending. This can be supported by the following quotations: 
One area guide personally called me before a few minutes and he told me that he is selling coconut and he requested from me to give him coconuts from the hotel estate for his business (Respondent 2, Personal Interview, 2020).

One of my friend, a tuk-tuk driver, who used to be at the junction has told me that he is now a mobile fish seller. Simply, many people are helpless and have gone for alternative income sources; their lifestyle is changed with the impact on income. We had a totally tourism-based economy in the area (Respondent 8, Personal Interview, 2020).

Further, Sri Lankan government stakeholders have been paid attention to developing alternative income sources for tourism service providers by reestablishing agriculturally based activities. Specifically, stakeholders believed that there is a high potentiality in the areas like Uva Province in Sri Lanka for export crops such as turmeric, ginger, Vanilla, Aloe vera, etc., which has a high demand in the export market.

The findings reveal that some people have already returned their traditional agricultural activities with the collapse in the tourism industry over months. The key issue in this strategy is the limited agricultural land in the area. But the government does not recommend the mobilization of tourism resources entirely into agriculture. The recommendation is to use some unused or underused land areas to grow herbs and spices, which can be used in addition with other sectors of the economy including medical tourism, herbal gardens or organic products.

\section{Encouraging domestic tourism}

Tourism industry stakeholders still believe that tourism is a viable solution for economic development in the regions by challenged the global pandemic. However, the global epidemic has affected a vast majority of countries and would-be travelers are reluctant to travel owing to the potential risks posed to their health:

This is the nature of tourism industry. Always, it is affected with external shocks. Still we can keep good hopes with local travelers until the things will become normal very sooner (Respondent 7, Personal Interview, 2020).

Although international traveling has been restricted (and these restrictions have increased or lessened depending on the viral spread), local tourism, especially the family travelers, has restarted during the new normal pandemic situation. Many hotels offer favorable packages focusing on the local tourists. The government has already prepared a promotional plan to develop local tourism as a strategy to reestablish the tourism economy in the area:

Yes, of course, I still trust that we have a future in the tourism industry. Also, there are ups and downs; I think we can still keep hopes for future. The local tourism is already started up to some extent. Families are traveling with private vehicles and now we have started to focus on them. We hope, when things are getting normal within next year and, then, foreigners will start to travel sooner (Respondent 3, Personal Interview, 2020).

\section{Adaptive planning for tourism restarting}

Stakeholders are still keeping expectations of the tourism industry. But they strongly believe that there should be a strong marketing campaign to communicate to other countries that Sri Lanka is a safer destination to travel:

I recommend engaging in alternative income sources for the survival for those who are in tourism businesses. We still have good hopes for the future. Most importantly there should be a strong marketing campaign to communicate other countries that Sri Lanka is a safer destination to travel during COVID 19 (Respondent 6, Personal Interview, 2020).

Impact of the COVID-19 pandemic 
WHATT

13,3

Stakeholders are planning for new marketing and promotion campaigns focusing the new normal operation. They are highly focused on conducting social media marketing, virtual banquets and virtual meeting arrangements in the hotel:

Other than that if we can control the situation within a shorter period of time. Otherwise, if the situation continues for a longer period like more than a year, the things will become worse and more severe impacts can be occurred unbearably (Respondent 7, Personal Interview, 2020).

According to the stakeholders' perspective, there will be longer staying inbound guests in the future when the pandemic here in Sri Lanka is controlled, and it is expected to receive more income through the tourist arrivals as they travel after a longer period of time.

Furthermore, strong attention should be paid to identifying the precise target market and should be launched a successful marketing campaign to attract and retain the industry resources. Moreover, findings suggested focusing mainly on the natural resources with rural and traditional culture.

Government authorities should be constantly communicated with stakeholders to cater to the potential demand with the opening of the international airport. The tourist hotel owners are ready to welcome the guests from the world based on the necessary guidelines and institutional support.

\section{Innovative practices to cope with changing consumers behavior}

The pandemic has revealed the need for a strategy that goes beyond national boundaries and enhances regional integration based on innovations that are interlinked between countries and between their production systems. Stakeholders in the tourism industry are moving toward innovative practices in the sectors which will help to survive during environmental shocks leading to noble hope for the future industry:

It is better if government can motivate and give knowledge to hoteliers about organic food, home gardening concepts and make a system to analyze and guiding them continuously (Respondent 7 , Personal Interview, 2020).

Organic gardening was proposed by some of the respondents as a survival strategy for tourism operators. They specifically highlighted the potential opportunity for growing vegetables along with the hotel operations. This can be considered as a contingency plan which would be an incentive to transfer to the organic concept and to survive by selling vegetables and fruits once the sudden pandemic hit the lives of the operators.

Moreover, stakeholders have emphasized resource mobilization and shifting the scope beyond the conventional hotel operation by moving more toward banquet operation and meetings, incentives, conferences and exhibitions market.

\section{Keeping interest and strengthening the parties}

Moreover, it was revealed that the provincial tourism ministries in Sri Lanka has initiated awareness programs in collaboration with the Sri Lanka Tourism Development Authority to educate and aware the tourism service providers about strategic tourism hot spots in the country such as Ella, Haputhale, Nuwara Eliya and national health guidelines to rejuvenate the strategies for the tourism industry:

Young generation should give a more transparent experience and exposure towards the tourism industry especially in this type of situation (Respondent 5, Personal Interview, 2020). 
Furthermore, they stated that keeping the interest of the younger generation that engage with the tourism industry is important because they have less experience to face for this type of global impact. Hence, it is important to strengthening stakeholders' mindset in such situation.

\section{Training and developments}

During high demand periods of operation, prior to COVID-19, the tourism related business operations did not have sufficient time to organize training sessions. However, now they can get involve in these programs gather new knowledge during this period when the tourism demand is not high. This will help them to refresh their knowledge as well as think of new ways and means for the rebranding and reestablishing tourism in the area. The government has organized several training and development programs.

The COVID-19 pandemic has been granted leisure time for the tourism business operators to rebrand and enhance key aspects of their industry through accumulating the knowledge and novel operation practices that not only enhance the tourism infrastructure but also enhance the livelihoods of those working in the industry:

As the government, we have developed several training programs collaboration with state universities to encourage them too (Respondent 3, Personal Interview, 2020).

There should be more assistance such as training and development for tourism operators and the employees to carry on operations successfully after restarting. For that stakeholders are expected to get support from universities and Sri Lanka Institute of Tourism and Hotel Management for this process.

\section{Managing the credit risk and financial insecurity of service providers}

Impacted parties from the COVID-19 Pandemic have been granted tax relief by the government after the Easter attack. In addition, the government has granted a grace period for loan repayment and vehicle leasing payment. Furthermore, the government has introduced a new loan scheme for lower interest rates, especially for the tourism business operators which would be supported to maintain the resources aligned:

I think Sri Lankan government is doing a wonderful job during this pandemic compared to many other countries in the world specially to manage the financial problems (Respondent 3, Personal Interview, 2020).

Moreover, a new working capital loan has been introduced by the government for those who have registered their operation under the Sri Lanka Tourism Development Authority.

Stakeholders stated that the government should further continue these tax reliefs and other financial reliefs such as lower interest rates. Moreover, they proposed the government introduce a novel insurance policy related to the health and safety of guests and employees to encourage engagement in the tourism industry.

\section{Defensive measures for existing foreign travelers}

Sri Lanka has also imposed defensive measures for existing foreign travelers such as visa extension without any excess payments or documents, permitting on charter flights on request to return and facilitating and protecting free of charge:

As I have heard in the media, our priority is also given to essential travel for emergencies like medical flights or travel for public health, technical support, and diplomatic officers. Cargo transport should 
WHATT

13,3

380

also be arranged for medical, food, and energy supplies. Sick persons and people with chronic diseases or underlying health conditions should delay or avoid traveling internationally.

Government has started following the gradual lifting of travel movement measures or transitory limitations depend on a careful risk assessment and the local epidemiology and transmission patterns. An analysis of the situation, the local context of departure and destination should be involved in the decision-making process.

\section{Recovery and resilience of Sri Lankan tourism}

The vigilant factor that all tourist destinations, including Sri Lanka, should adapt as a part of destination resilience and recovery is the implementation of a transitional and transformational approach. As a destination, a solid economic immunity equipped with governance and infrastructure should be ensured to endorse the safety and security of both supplier and consumer. Smart and more innovative product development and delivery mechanisms are fundamentally required for all levels in the tourism value delivery network.

The resilience of MSME sector should be strategically enhanced with a sufficient level of contingency plans. Sri Lanka has never faced such a vulnerable disease ever before in history. Hence, the importance of business resilience or contingency planning was not strategically identified. Hence, the two robust approaches recommend affords system resilience and destination resilience in a collateral way. To achieve this goal, Sri Lanka should have holistic short-term and long-term plans.

\section{Conclusion and recommendations}

The emergence of COVID-19 in 2019 in the city of Wuhan, China and the tourism industry becoming one of the primary facilitators in transporting the virus around the globe has created immense challenges for tourism and related industries. This study explores the resilience potentials under the developing conditions of the pandemic as well as stakeholder perceptions on the future industry operations. The study is expected to guide policymakers and operators in critical decision making under the challenged circumstances of all stakeholders. The tourism industry in Sri Lanka has gone through a series of national challenges since its emergence in 1960s. Equally, the tourism industry of Sri Lanka has "bounced back" from challenging circumstances disasters.

At the time of this study, industry conditions were in a full standstill while stakeholders continue to loose income, have higher interest loan payback schedules, decline in employees and payroll, and issues with ongoing investments. The pandemic has allowed industry stakeholders to focus on domestic tourism and offered an opportunity to revise many out-ofdate practices. Thus, the study argues that resilience building should be the key priorities of all responsible parties including the local tourists. Equally, survival under the evolving conditions has become the central focus of all stakeholders; industry survival measures should urgently be recognized, implemented, and supported to make sure a robust "bounce back" once the tourism and hospitality operations return to a place of normalcy.

\section{Note}

1. In 21 April 2019, Easter Sunday, three churches in Sri Lanka and three luxury hotels in the commercial capital, Colombo, were targeted in a series of coordinated Islamic terrorist suicide bombings. A total of 267 people were killed, including at least 45 foreign nationals, three police officers and eight bombers, and at least 500 were injured. The church bombings were carried out during Easter services in Negombo, Batticaloa and Colombo; the hotels that were bombed were the Shangri-La, Cinnamon Grand, Kingsbury and Tropical Inn. 


\section{References}

Arsarathnam, S. (2004), "Sri Lanka: Encyclopedia Britannica”.

Becken, S. (2013), "Developing a framework for assessing resilience of tourism subsystems to climatic factors", Annals of Tourism Research, Vol. 43, pp. 506-528.

Cochrane, J. (2008), “Asian tourism: growth and change”, ISBN: 9780080453569.

Cohen, S.A., Prayag, G. and Moital, M. (2014), "Consumer behaviour in tourism: concepts, influences and opportunities", Current Issues in Tourism, Vol. 17 No. 10, pp. 872-909.

Dahles, H. and Susilowati, T.P. (2015), "Business resilience in times of growth and crisis", Annals of Tourism Research, Vol. 51, pp. 34-50.

Davoudi, S. (2012), "Resilience: a bridging concept of a dead end?", Planning Theory and Practice, Vol. 13 No. 2, pp. 299-333.

Esu, B.B. and Ebitu, E. (2010), "Promoting an emerging tourism destination", Global Journal of Management and Business Research, Vol. 10 No. 1.

Folke, C. (2005), "Resilience: the emergence of a perspective for social-ecological systems analyses", Global Environmental Change, Vol. 16 No. 3, pp. 253-267.

Hudson, R. (2010), "Resilient regions in an uncertain world: wishful thinking or practical reality?", Cambridge Journal of Regions, Economy and Society, Vol. 3 No. 1, pp. 11-25.

Karunarathne, A.C.I.D. (2015), "A footstep towards rural tourism- an empirical market analysis centered to Ella - Bandarawela, Sri Lanka”, Journal of Business Studies. Faculty of Management Studies and Commerce, University of Jafna, Sri Lanka.

Korinth, B. and Ranasinghe, R. (2020), "Covid-19 pandemic's impact on tourism in Poland in march 2020".

Lew, A. (2014), "Scale, change and resilience in community tourism planning”, Tourism Geographies, Vol. 16 No. 1, pp. 14-22.

Media Center of Ministry of Tourism and Aviation (2020), Ministry of Tourism and Aviation, SLTDA and UNDP co-convene meeting with development partners on building a more resilient tourism sector in Sri Lanka, United Nations Sri Lanka, available at: https://k.one.un.org/news/ministryof-tourism-and-aviation-sltda-and-undp-co-convene-meeting-with-development-partners-onbuilding-a-more-resilient-tourism-sector-in-sri-lanka/ (accessed 10th June 2020).

Mukhopadhyay, A. (2020), "How Sri Lanka successfully curtailed the coronavirus pandemic, Deutsche Welle (DW), available at: https://www.dw.com/en/how-sri-lanka-successfully-curtailed-thecoronavirus-pandemic/a-53484299 (accessed 12th June 2020).

PWC (2020), “COVID-19”, Impact on Sri Lanka and Recommendations

Ranasinghe, R., Damunupola, A., Wijesundara, S., Karunarathna, C., Nawarathna, D., Gamage, S. and Idroos, A.A. (2020). "Tourism after Corona: impacts of Covid 19 pandemic and way forward for tourism, hotel and MICE industry in Sri Lanka”, Hotel and Mice Industry in Sri Lanka (April 22, 2020).

Ranasinghe, R., Karunarathna, C. and Pradeepamali, J. (2020), After Corona (COVID19) Impacts on Global Poverty and Recovery of Tourism Based Service Economies: An Appraisal, doi: 10.2139/ ssrn.3591259.

Samarathunga, W.H.M.S. (2020), "Post-COVID19 challenges and way forward for Sri Lanka tourism", Available at SSRN 3581509.

Scott, D., de Freitas, C. and Matzarakis, A. (2008), "Adaptation in the tourism and recreation sector", in Ebi, K.L. and Burton, I. (Eds), Biometeorology for Adaptation to Climate Variability and Change, Kluwer Academic Publishing, Dordrecht, pp. 171-194.

Silva, D. (2019), Tourist Hotels Fear $\$ 1.5$ b Revenue Loss from Terror Attacks, Daily FT.

Sri Lanka Tourism Development Authority (2007), Annual Statistical Report.

Sri Lanka Tourism Development Authority (2019), Annual Statistical Report. 


\section{WHATT}

13,3

\section{2}

Sri Lanka Tourism Development Authority (2020), Annual Statistical Report.

Ungar, M. (2003), “Qualitative contributions to resilience research", Qualitative Social Work, Vol. 2 No.1, pp. 85-102.

Weerathunga, P.R., Xiaofang, C., Samarathunga, W.H.M.S. and Jayathilake, P.M.B. (2020), "The relative effect of growth of economy, industry expansion, and firm-specific factors on corporate hotel performance in Sri Lanka", SAGE Open, Vol. 10 No. 2, p. 2158244020914633.

Wilson, A. (2018), Sri Lanka ranked top country for travel in 2019 by Lonely Planet, The Guardian, available at: www.theguardian.com/trave1/2018/oct/23/sri-lanka-ranked-top-country-for-travelin-2019-by-lonely-planet\#: :text=Almost $\% 2010 \% 20$ years $\% 20$ after $\% 20$ the,in $\% 202019 \%$ 20by $\%$ 20Lonely \%20Planet (accessed 09th June 2020).

Xinhua (2018), Sri Lanka Ranked No 1 Travel Destination in 2019 by Lonely Planet, ChinaDaily.com

Yusuf, J.E.W., John, B.S., Rawat, P., Covi, M., Nicula, J.G. and Considine, C. (2019), “The action-oriented stakeholder engagement for a resilient tomorrow (ASERT) framework: an effective, field-tested approach for engaging stakeholders", Journal of Environmental Studies and Sciences, Vol. 9 No. 4, pp. 409-418.

\section{Further reading}

Claveria, O. (2016), "Positioning emerging tourism markets using tourism and economic indicators", Journal of Hospitality and Tourism Management, Vol. 29, pp. 143-153.

\section{Corresponding author}

A.C.I.D. Karunarathne can be contacted at: chandi@uwu.ac.lk

For instructions on how to order reprints of this article, please visit our website: 